\title{
A study of effects of hypothyroidism on antenatal patients
}

\author{
Payal Saha*, Tushar Palve, Pooja R.
}

Department of Obstetrics and Gynaecology, Grant Government Medical College, Mumbai, Maharashtra, India

Received: 21 October 2021

Accepted: 26 November 2021

\author{
*Correspondence: \\ Dr. Payal Saha, \\ E-mail: sahapaya194@gmail.com
}

Copyright: (c) the author(s), publisher and licensee Medip Academy. This is an open-access article distributed under the terms of the Creative Commons Attribution Non-Commercial License, which permits unrestricted non-commercial use, distribution, and reproduction in any medium, provided the original work is properly cited.

\begin{abstract}
Background: After diabetes mellitus, thyroid disorders are the most common endocrine disorders in pregnancy. The most common thyroid gland dysfunction in pregnancy is hypothyroidism with estimated prevalence of $1.5-4.4 \%$ of pregnant women. Effects of hypothyroidism in pregnancy include anemia, pre-eclampsia, prematurity, IUGR, low birth weight, mental retardation in neonate. The objective of this study is to find the association of hypothyroidism and its adverse outcomes on mother and the fetus that is listed above.

Methods: A study was conducted over a period of 6 months over 50 antenatal patients with hypothyroidism from Jan 2021 to August 2021 in the department of obstetrics and gynecology, Cama and Albless hospital, Mumbai with inclusion, exclusion criteria. History of infertility, family history of thyroid disease, menstrual pattern, recurrent abortion and fetal outcomes were the main study variables.

Results: In this study, majority of hypothyroidism belonged to the age group of 26-30 years (54\%). A high prevalence was found in G2 (26\%) and antenatal hypothyroidism with past $\mathrm{h} / 0$ abortions were found in $26 \%$ patients. Low birth weight is found in $32 \%$ cases of hypothyroidism, NICU admissions seen in $32 \%$ cases of hypothyroidism, $22 \%$ cases were found to have anemia.

Conclusions: Hypothyroidism is a common health problem in antenatal patients. We concluded that hypothyroidism is more commonly seen to be associated with low birth weight, anemia, pre-eclampsia, NICU admission in neonate. Early ANC registration and regular ANC checkups help in early recognition and initiating early treatment, thus improving fetomaternal outcome.
\end{abstract}

Keywords: Hypothyroidism, Low birth weight, Antenatal, Anemia

\section{INTRODUCTION}

After Diabetes Mellitus, thyroid disorders are the most common endocrine disorders during pregnancy. ${ }^{1}$ The most common thyroid gland dysfunction in pregnancy is hypothyroidism. It is estimated that the prevalence is 1.5$4.4 \%$ of pregnant women. ${ }^{1}$ With hypothyroidism many had history of recurrent abortions and also complications during antenatal period like preeclampsia, abruption placenta, IUGR and preterm delivery. ${ }^{2}$ Effects of hypothyroidism in pregnancy are anemia, low birth weight and mental retardation in neonate. The objective of this study is to find the association of hypothyroidism and its adverse outcomes on mother and the fetus which is listed above.

\section{METHODS}

A prospective clinical study was conducted over a period of 6 months over 50 antenatal patients with Singleton pregnancy with hypothyroidism from Jan 2021 to August 2021 in the department of obstetrics and gynecology, Cama and Albless hospital, Mumbai with inclusion, exclusion criteria. Detailed history taken and examination done and blood sample collected and sent for serum TSH, T3, T4 levels. History of infertility, family history of thyroid disease, menstrual pattern, recurrent abortion and fetal outcomes were the main study variables with the following inclusion- exclusion criteria. Data was analyzed in Microsoft excel software for statistical correlation. 


\section{Statistical analysis}

Statistical analysis is done by SPSS software and difference with a $\mathrm{p}<0.05$ was considered statistically significant.

\section{Inclusion criteria}

Antenatal patients with 30 weeks or more than 30 weeks gestation and antenatal patients giving consent for the study were included in the study.

\section{Exclusion criteria}

Antenatal patients having hypothyroidism prior to pregnancy or any other autoimmune disease and those not willing to participate in the study. were excluded from the study.

\section{RESULTS}

A total of 50 antenatal patients with hypothyroidism participated in this study and the following observations were made.

\section{Parity and hypothyroidism}

Table 1: Parity.

\begin{tabular}{|c|c|c|}
\hline Parity & $\begin{array}{l}\text { No. of } \\
\text { cases }\end{array}$ & Percentage $(\%)$ \\
\hline Primigravida & 12 & 24 \\
\hline G2 & 13 & 26 \\
\hline G3 & 6 & 12 \\
\hline G4 & 2 & 4 \\
\hline G2A1/G3A2 & 13 & 26 \\
\hline $\begin{array}{l}\text { Bad obstetric } \\
\text { history }\end{array}$ & 4 & 8 \\
\hline
\end{tabular}

In this study, a higher percentage of hypothyroidism was found in $\mathrm{G} 2$ (26\%) followed by primigravida (24\%), G3 $(12 \%),>\mathrm{G} 4(4 \%)$, and $26 \%$ patients had previous history of abortion

\section{Period of gestation}

Among the 50 antenatal patients, 28 patients (56\%) delivered between $38-40$ weeks, 11 patients $(22 \%)$ delivered $>40$ weeks, 11 patients $(22 \%)$ delivered before the 37 weeks.

Table 2: Period of gestation.

\begin{tabular}{|lll|}
\hline $\begin{array}{l}\text { Period of gestation } \\
\text { (Weeks) }\end{array}$ & $\begin{array}{l}\text { No. of } \\
\text { cases }\end{array}$ & Percentage $(\%)$ \\
\hline$<37$ & 11 & 22 \\
\hline $\mathbf{3 8 - 4 0}$ & 28 & 56 \\
\hline$>\mathbf{4 0}$ & 11 & 22 \\
\hline
\end{tabular}

\section{Mode of delivery}

In this study, $58 \%$ patients had full term vaginal delivery, $34 \%$ patients underwent caserean section, $8 \%$ patients had preterm vaginal delivery.

Table 3: Mode of delivery.

\begin{tabular}{|lll|}
\hline Mode of delivery & $\begin{array}{l}\text { No. of } \\
\text { cases }\end{array}$ & Percentage $(\%)$ \\
\hline $\begin{array}{l}\text { Full term vaginal } \\
\text { delivery }\end{array}$ & 29 & 58 \\
\hline LSCS & 34 & 34 \\
\hline $\begin{array}{l}\text { Preterm vaginal } \\
\text { delivery }\end{array}$ & 8 & 8 \\
\hline
\end{tabular}

\section{Birth weight of baby}

In this study, $56 \%$ babies had birth weight between 2501 $3000 \mathrm{gm}, 32 \%$ had low birth weight $(<2500 \mathrm{gm}), 8 \%$ babies had birth weight between 3501-400 gm, 4\% babies had birth weight $>4000$ gm. $^{1}$

Table 4: Birth weight.

\begin{tabular}{|lll|}
\hline Birth weight $(\mathrm{gm})$ & No. of cases & $\begin{array}{l}\text { Percentage } \\
(\%)\end{array}$ \\
\hline $\begin{array}{l}\text { Less than or equal } \\
\text { to 2500 }\end{array}$ & 16 & 32 \\
\hline $\mathbf{2 5 0 1 - 3 0 0 0}$ & 28 & 56 \\
\hline $\mathbf{3 0 0 1 - 4 0 0 0}$ & 4 & 8 \\
\hline $\mathbf{7 4 0 0 1}$ & 2 & 4 \\
\hline
\end{tabular}

\section{NICU admission with hypothyroidism}

In this study, $32 \%$ babies required NICU admission due to various reasons, $68 \%$ babies did not require NICU admission.

Table 5: NICU admission.

\begin{tabular}{|lll|}
\hline $\begin{array}{l}\text { NICU admission } \\
\text { required }\end{array}$ & No. of cases & Percentage $(\%)$ \\
\hline Yes & 16 & 32 \\
\hline No & 34 & 68 \\
\hline
\end{tabular}

Table 6: Co-morbidities with hypothyroidism.

\begin{tabular}{|lll|}
\hline Co-morbidities & No. of cases & Percentage $(\%)$ \\
\hline Anemia & 10 & 20 \\
\hline Pre-eclampsia & 12 & 24 \\
\hline Polyhydramnios & 6 & 12 \\
\hline Neonatal death & 2 & 4 \\
\hline
\end{tabular}

\section{Co-morbidities with hypothyroidism}

Among 50 antenatal patients with hypothyroidism, anemia was observed in $20 \%$ patients, pre-eclmapsia was observed 
in $24 \%$ patients, polyhydramnios in $12 \%$ patients, neonatal death in $4 \%$ patients.

\section{DISCUSSION}

In our study, higher percentage of hypothyroidism was found in G2 (26\%) followed by primigravida (24\%), G3 $(12 \%),>\mathrm{G} 4(4 \%)$ and $26 \%$ patients had previous history of abortion. Similar results were found in a study conducted by Mahadik et al where the prevalence of abortions was found to be high. ${ }^{2}$

Among 50 antenatal patients, 28 patients $(56 \%)$ delivered between 38-40 weeks, 11 patients $(22 \%)$ delivered $>40$ weeks, 11 patients (22\%) delivered before 37 weeks (preterm). In a study conducted by Korevaar et al the preterm delivery risk was found to be $6.1 \% .^{4}$

In this study, $32 \%$ babies required NICU admission due to various reasons, $68 \%$ babies did not require NICU admission. Similar results were found in a study conducted by Mahadik et al where the rate of NICU admission was $42.1 \% .^{2}$

In this study, $56 \%$ babies had birth weight between 2501 $3000 \mathrm{gm}, 32 \%$ had low birth weight $(<2500 \mathrm{gm}), 8 \%$ babies had birth weight between 3501-400 gm, 4\% babies had birth weight $>4000 \mathrm{gm}$. Similar results were found in a study conducted by Mahadik et al where low birth weight was found in $31.6 \%$ patients. $^{2}$

In this study, $58 \%$ patients had full term vaginal delivery, $34 \%$ patients underwent caserean section, $8 \%$ patients had preterm vaginal delivery. Similar results were found in a study conducted by Kiran et al where the emergency cesarean section occurred in $23.4 \%$ of cases. ${ }^{3}$

Among 50 antenatal patients with hypothyroidism, anemia was observed in $20 \%$ patients, pre-eclmapsia was observed in $24 \%$ patients, polyhydramnios in $12 \%$ patients, neonatal death in $4 \%$ patients. Similar results were found in a study conducted by Mahadik et al where anemia was found in 26.3 patients. $^{2}$

\section{Limitations}

This study being the neurocognitive function of babies could not be studied in detail due to lost to follow up of patients. All laboratory parameters should be studied to come to a diagnosis.

\section{CONCLUSION}

Hypothyroidism is a common health problem in antenatal patients. We concluded that hypothyroidism is more commonly seen to be associated with low birth weight, anemia, pre-eclampsia, NICU admission in neonate. Early ANC registration and regular ANC checkups help in early recognition and initiating early treatment, thus improving fetomaternal outcome.

\section{Funding: No funding sources}

Conflict of interest: None declared

Ethical approval: The study was approved by the Institutional Ethics Committee

\section{REFERENCES}

1. Shrestha A, Tripathi P, Dongol A. Pregnancy Outcomes in Patients with Hypothyroidism. Kathmandu Univ Med J (KUMJ). 2019;17(65):57-60.

2. Mahadik K, Choudhary P, Roy PK. Study of thyroid function in pregnancy, its feto-maternal outcome; a prospective observational study. BMC Pregnancy Childbirth. 2020;20(1):769.

3. Kiran Z, Sheikh A, Malik S, Meraj A, Masood M, Ismail $S$ et al. Maternal characteristics and outcomes affected by hypothyroidism during pregnancy (maternal hypothyroidism on pregnancy outcomes, MHPO-1). BMC Pregnancy Childbirth. 2019;19(1):476.

4. Consortium on Thyroid and Pregnancy-Study Group on Preterm Birth, Korevaar TIM, Derakhshan A, Taylor PN, Meima M, Chen L, Bliddal S et al. Association of Thyroid Function Test Abnormalities and Thyroid Autoimmunity With Preterm Birth: A Systematic Review and Meta-analysis. JAMA. 2019;322(7):632-41.

5. Nazarpour S, Ramezani Tehrani F, Simbar M, Azizi F. Thyroid dysfunction and pregnancy outcomes. Iran J Reprod Med. 2015 Jul;13(7):387-96.

6. Dosiou C. Thyroid and Fertility: Recent Advances. Thyroid. 2020;30(4):479-86.

7. Lee SY, Cabral HJ, Aschengrau A, Pearce EN. Associations Between Maternal Thyroid Function in Pregnancy and Obstetric and Perinatal Outcomes. J Clin Endocrinol Metab. 2020;105(5):e2015-23.

8. Derakhshan A, Peeters RP, Taylor PN, Bliddal S, Carty $\mathrm{DM}$, Meems $\mathrm{M}$ et al. Association of maternal thyroid function with birthweight: a systematic review and individual-participant data meta-analysis. Lancet Diabetes Endocrinol. 2020;8(6):501-10.

9. León G, Murcia M, Rebagliato M, lvarez-Pedrerol M, Castilla AM et al. Maternal thyroid dysfunction during gestation, preterm delivery, and birthweight. The Infancia y Medio Ambiente Cohort, Spain. Paediatr Perinat Epidemiol. 2015;29(2):113-22.

10. Iwen KA, Lehnert $\mathrm{H}$. Thyroid and pregnancy. Internist (Berl). 2018;59(7):654-60.

11. Cunningham FG, Leveno KJ, Bloom SL, Dashe JS, Spong CY, Hoffman BL et al. Williams Obstetrics, $25^{\text {th }}$ edition, endocrine disorders. 2018.

Cite this article as Saha P, Palve T, Pooja R. A study of effects of hypothyroidism on antenatal patients. Int J Reprod Contracept Obstet Gynecol 2022;11:169-71. 